\title{
MEDICALLY IMPORTANT BEETLES (INSECTA: COLEOPTERA) OF IRAN
}

\section{NIKBAKHTZADEH MR (1), TIRGARI S (2)}

(1) Department of Medical Parasitology and Entomology, College of Medical Sciences, Tarbiat Modares University, Tehran, Iran; (2) Department of Medical Entomology and Vector Control, School of Public Health, Tehran University of Medical Sciences, Tehran, Iran.

\begin{abstract}
This study focused on coleopteran species that are responsible for the emergence of recent cases of dermatological manifestations in Iran. To the best of our knowledge, five species of the family Meloidae and nine species of the genus Paederus are by far the only beetles recognized as medically important in Iran. The staphylinids consists of Paederus ilsae, $P$. iliensis, $P$. fuscipes, $P$. kalalovae, $P$. balcanicus, $P$. lenkoranus, $P$. littoralis, $P$. carpathicus, $P$. nigricornis, while the meloids are Mylabris impressa, M. guerini, Muzimes iranicus, Alosimus smyrnensis and Epicauta sharpi. Most cases of linear dermatitis in this country occur in areas bordering the Caspian Sea. This problem is caused by beetles of the genus Paederus which are present as adults from mid-April to October with particularly high incidences from May to August. Fars (in southern Iran) ranks second in number of cases of insect-induced dermatitis. The third major region in which this type of dermatitis has been recorded is Hamedan Province, in the west of the country. Meloid dermatitis showed its highest severity in 2001, when a considerable number of patients sought medical help in Toyserkan and Nahavand counties. New cases of skin blistering were reported along the Persian Gulf coast and the agent was identified as Epicauta sharpi (Coleoptera: Meloidae). In all these regions, it was observed that recorded cases of lesions coincided precisely with the yearly peaks of the beetles. Paederus fuscipes and $P$. kalalovae are the predominant species along the Caspian Sea shore. It appears that $P$. fuscipes is homogeneously distributed throughout the Caspian Sea region while the distribution of the other species is more irregular. Paederus fuscipes is probably the major agent that causes linear dermatitis in northern Iran. Whereas this disease is a rural difficulty in the south, mainly in villages or small towns, it is an urban problem in northern provinces along the Caspian Sea shore. Meloid dermatitis has been registered only in western and southern Iran. It is not as widespread as linear dermatitis and remains a minor rural health problem.
\end{abstract}

KEY WORDS: Meloidae, Staphylinidae, Paederus, beetle, dermatitis, pederin, cantharidin, Iran.

CONFLICTS OF INTEREST: There is no conflict.

\section{CORRESPONDENCE TO:}

MAHMOOD REZA NIKBAKHTZADEH, Department of Medical Parasitology and Entomology, College of Medical Sciences, Tarbiat Modares University, PO box: 14115-331, Tehran, Iran. Fax: +98 21 88013030. Email: nikbakht m@excite.com. 


\section{INTRODUCTION}

Several beetle families (Insecta: Coleoptera) have been reported as medically important. Meloidae, Staphylinidae, Tenebrionidae and Dermestidae families are responsible for most of the complaints related to human health. However, other families, including Oedemeridae, Coccinellidae, Paussidae, Cucujidae, Corylophidae and Scarabaeidae, can also afflict humans $(2,19)$. The commonest symptoms observed are skin lesions $(6,16,41)$ as well as respiratory $(1)$, eye (28) or skin allergies (44), arising from contact with beetle hemolymph and/or toxic secretions (18), larval hairs (12) or frass $(2,19)$.

Although many medically important beetles are present in Iran, only a few reports on the health impacts of these animals on the local population are available. Herein, we focused this study on coleopterans that are responsible for recent cases requiring medical attention.

The first document on a medically significant coleopteran, dating back to the 1970's (21), reports injuries from the genus Paederus (Coleoptera: Staphylinidae) in northern Iran. Paederus beetles have been known in western medicine, for their toxicity, for over 100 years. Worldwide, 622 species have been recognized so far (17). Adults of many, though not all species, produce toxins that circulate in their hemolymph. These toxins are three closely-related molecules having a complex tetrahydropyran ring and unknown in other insect genera. The first-described and best-characterized molecule is called pederin (Figure 1). Its release on human skin typically occurs inadvertently when one of these insects lands on a human and is crushed. Pederin penetrates skin without any abrasion. Its dermal effects have received several names in different countries, but the preferred one is linear dermatitis, because it predates other names and is widely applicable (18). Typical characteristics of linear dermatitis (Figure 2), occurring worldwide, are erythema, vesicle and squamous formation (42). 


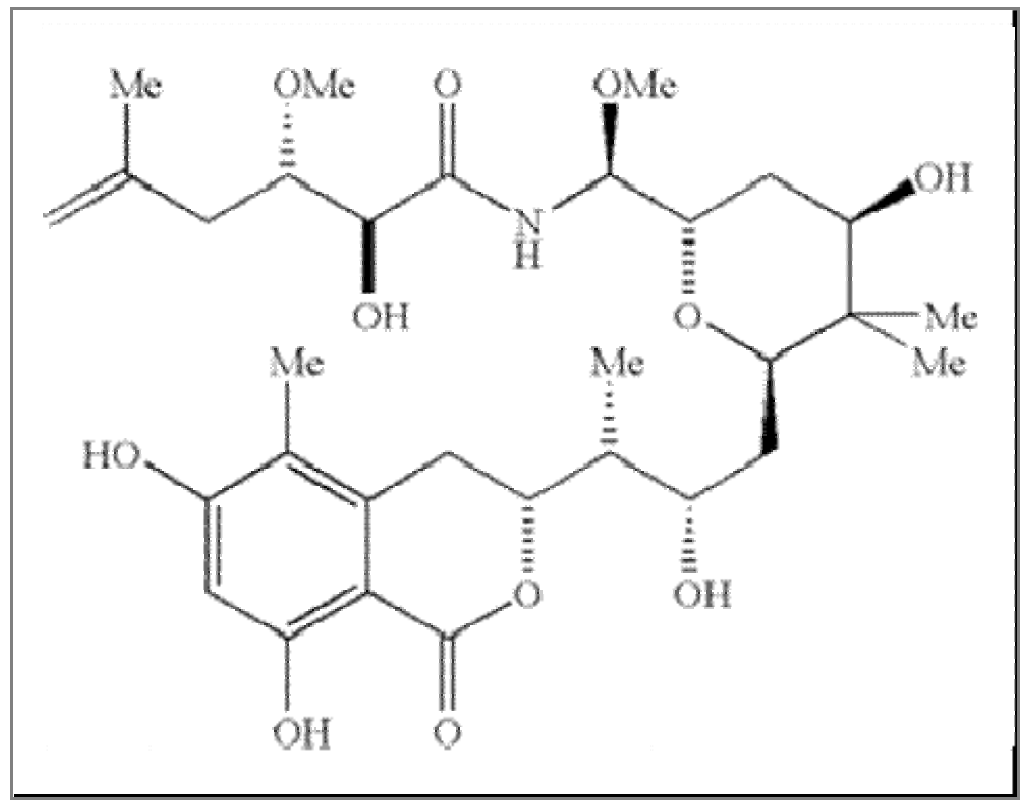

Figure 1. Pederin chemical structure.

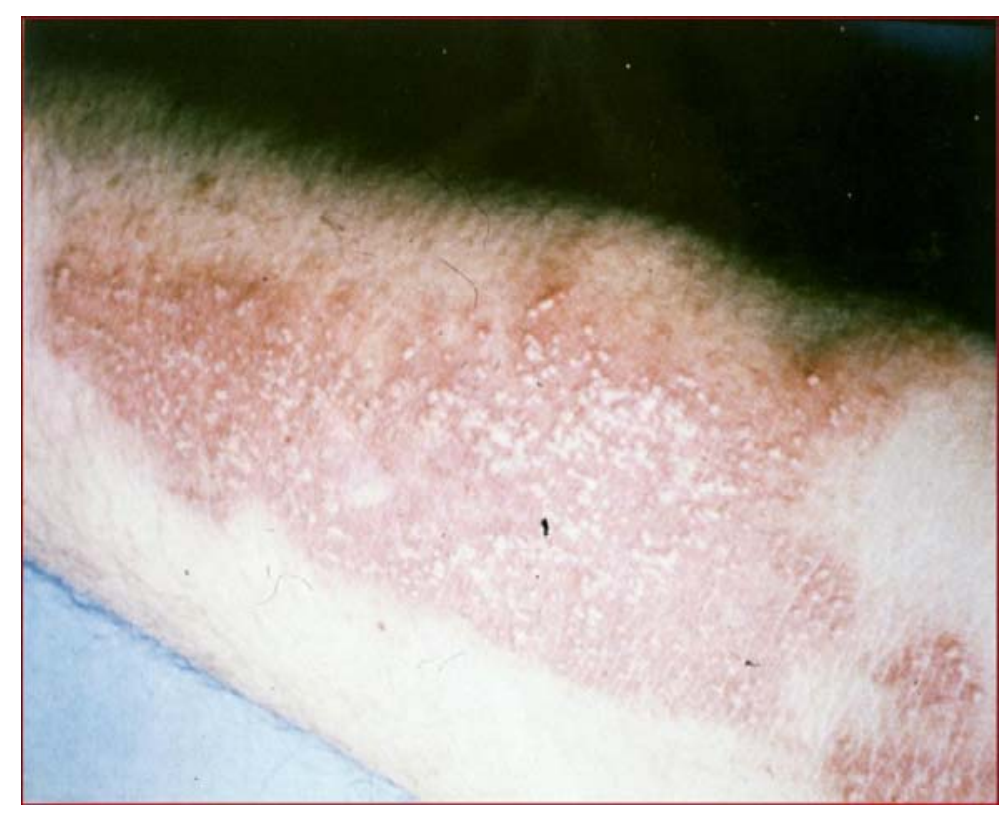

Figure 2. Linear dermatitis on an arm caused by Paederus fuscipes (northern Iran). Erythema and vesicles are the first two typical symptoms.

Janbakhsh and Ardalan (21) recorded three species, P. fuscipes, P. pietschmanni and $P$. spectabilis, along the Caspian Sea shore, but they only considered the first species the causative agent of the observed dermatitis. Majidi-Shad et al. (25) added reports two more species, $P$. riparius and $P$. littoralis, from the same region. Nikdel (34) considered $P$. fuscipes the only species in the Caspian Sea region. The same key (36), used by all these researchers in order to identify the species, covered only 
the eight known species of the French fauna; hence, it could not form a reliable basis for any conclusions. Furthermore, the authors did not indicate the relative abundance of the reported species or the major agent of the Paederus dermatitis. A more consistent approach was performed by Nikbakhtzadeh and Tirgari (33), who reported two species of $P$. ilsae and $P$. iliensis from southern Iran, determined their relative abundance and studied the ecological and seasonal activity of each species. In this case, a strong relationship between the beetles themselves and the resultant lesions was also established in the studied area (33). However, it should be noted that studying Paederus species is by no means easy, as the fauna is largely unknown and contains hundreds of species. Currently, there is no comprehensive publication or identification key available for the Paederus species of Iran.

Since our earlier reports $(30,43)$, more Paederus species across a considerably broader geographic distribution have been recorded. Additionally, several members of the family Meloidae - the so-called blister beetles - have also been indicated as dermatitis agents among some residential localities in western Iran.

The blistering compound, cantharidin (Figure 3), which is mainly found in meloids, is one of the most widely known insect natural products $(14,27)$. It is highly toxic to most animals ( $L D_{50}$ for humans is 10 to $60 \mathrm{mg} / \mathrm{kg}$ ) (14). Its reputation is principally derived from the description of its physiological activity as a blistering agent.

The family Meloidae is currently thought to contain 125 genera and 2,500 species (8). Eighteen meloid species have been reported as important agents causing blistering in humans (2). Different species of Mylabris, Lytta and Epicauta are responsible for many cases of dermal blisters and dermatitis reported every year from India and southwest USA $(2,24)$. Symptoms of meloid dermatitis vary from severe, but temporary, pains to large blisters (Figure 4). The hypersensitivity from meloid dermatitis is less severe than the delayed type hypersensitivity (16) from Paederus beetles (4). 


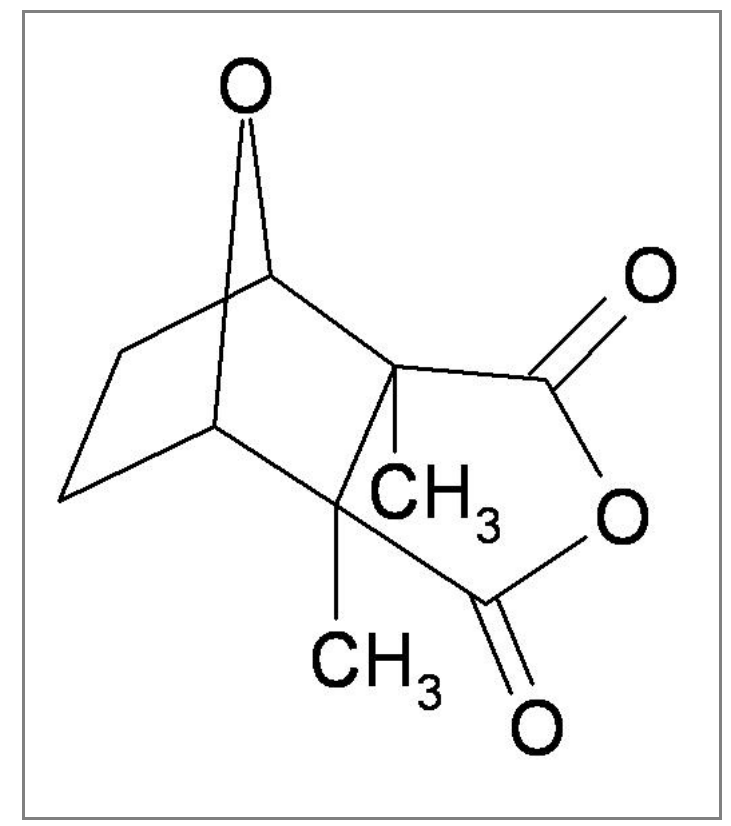

Figure 3. Cantharidin chemical structure.

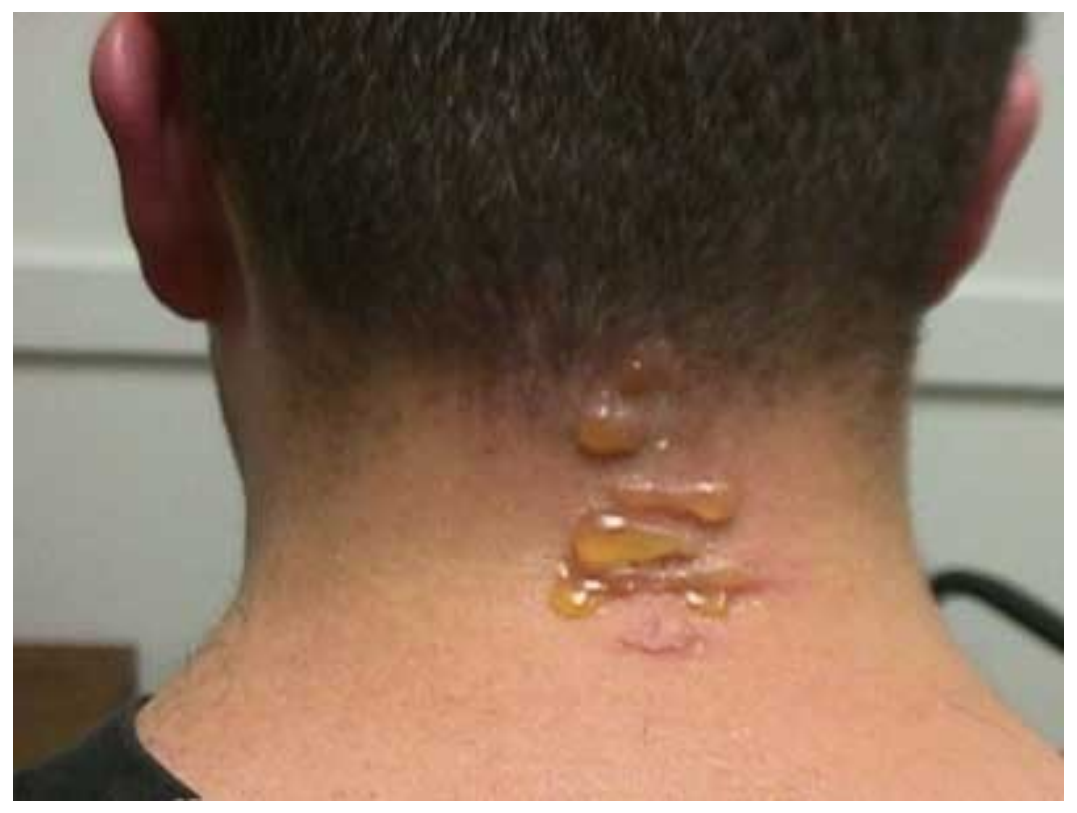

Figure 4. Blistering symptom provoked by a meloid beetle.

One hundred and forty-two species in 21 genera of blister beetles occur in Iran (31); however, the meloid fauna of this country is poorly known (3). The first report on the Iranian fauna was by Redtenbacher (37). Kaszab (22) substantially updated the knowledge of meloid beetles in Iran, whereas the latest research on these animals was conducted by Axentiev (3). So far, no report has been published on the medical 
significance of Iranian blister beetles or the distribution of medically important species.

In this paper we summarize what we have learned on the Iranian Coleoptera during a ten-year period of national studies (1997 to 2007), in order to illustrate a clearer portrait of faunal diversity among the medically important beetles, their distribution, predominant species and their role in the recent outbreaks of insect-induced dermal lesions and, finally, their ecological status. We excluded those coleopteran species for which no robust proof of affecting the local residents was available.

\section{MATERIALS AND METHODS}

\section{Medical Records}

The records of the Iranian national health network were reviewed to observe whether there were any significant reports of insect-induced dermatitis. In addition, the Department of Medical Entomology at Tehran University of Medical Sciences was, several times, directly informed of insect-induced dermatitis in the country between 1990 and 2002. From this, at least seven patients were referred to our laboratory for further investigations. We selected regions for additional study and sites for insect collection based on the abundance of the reported cases of insect-induced dermatitis. After the reports, we visited the region and collected the implicated insects either personally or by asking the patients to provide specimens. In this manner, we checked if the co-occurred insects had really induced the lesion. In the target regions, dermatologists and the emergency wards of the local hospitals were also consulted in order to verify the primary reports.

\section{Method of Collection and Identification}

Paederus studies started in March and continued until October, yearly, between 1997 and 2007. Over 9,000 specimens were collected in different parts of Iran. Collections were made by two methods. In daylight hours, beetles were detected visually among vegetation and collected by using an exhauster. Daylight collections were randomly made from various crop plants - mainly alfalfa and rice - and from weeds (Table 1). The daylight collection method also included use of a spade to check for the presence of the beetles in the soil cracks (Figure 5). Collected specimens were transferred to vials of $70 \%$ ethanol for subsequent identification. 
Table 1. Weeds serving as the habitats of Paederus species ${ }^{*}$

\begin{tabular}{ll}
\hline Scientific name & Common english name \\
\hline 1. Cynodon dactylon (L.) Pers. & Bermuda grass \\
2. Setaria spp. & Foxtail \\
3. Digitaria sp. & Crabgrass \\
4. Lolium sp. & Dornel \\
5. Aegilops sp. & Goatgrass \\
6. Echinochloa crusgalli (L.) Pers. Beauv. & Barnyardgrass \\
7. Plantago sp. & Plantain \\
8. Mentha pulegium L. & Spearmint \\
\hline
\end{tabular}

*The plants are numerically ordered based on their relative importance as non-crop habitats, while their relative abundance has not yet been calculated.

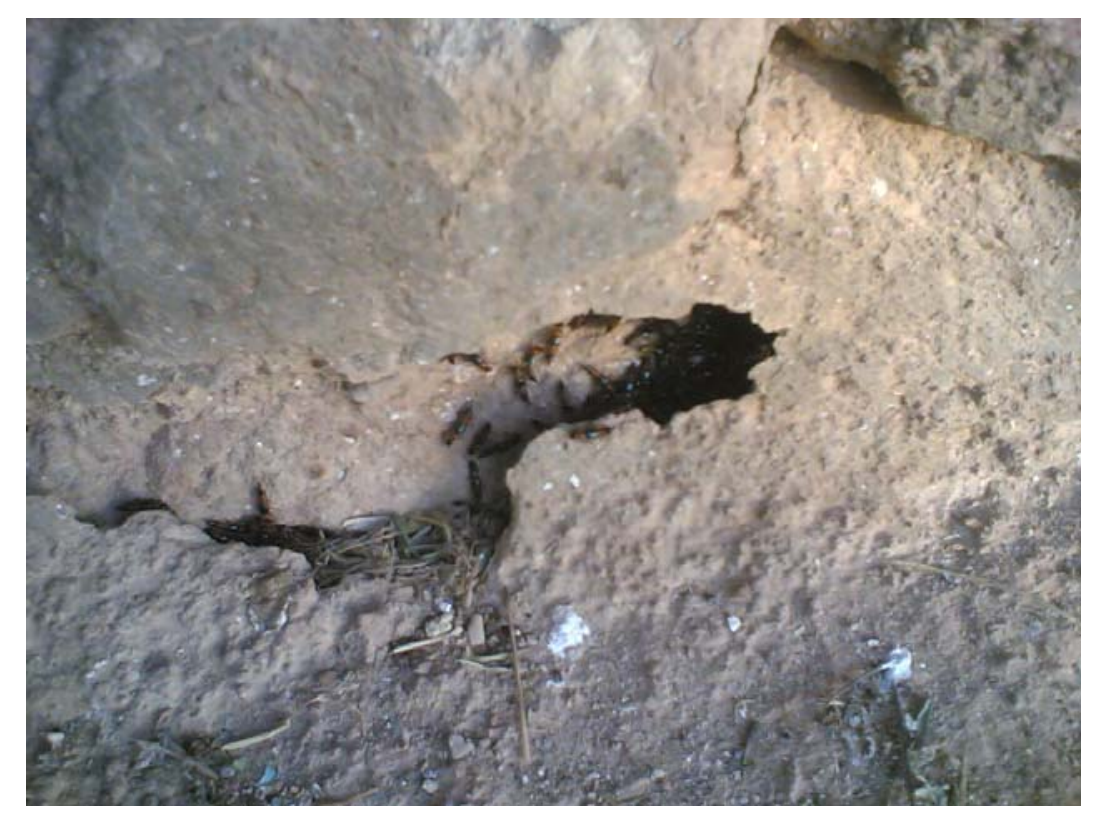

Figure 5. Soil cracks, an ideal place for adult individuals of Paederus genus, (Fars province, southern Iran).

At night, an ultraviolet (UV) black light was used to attract flying beetles. Although the beetles are also attracted to incandescent, fluorescent and neon lamps, longwave UV seems especially attractive to them. A UV black ray lamp (Model XX-15 ${ }^{\circledR}, 115$ volts, 60 cycles, 15 Watts, Ultra Violet Productions Inc., USA) was operated at twoweek interval at the selected locations from dusk until midnight. It was installed either on the wall of a building or on a metal pole, $2 \mathrm{~m}$ above ground level. Collecting the beetles in daylight hours led to the ability to select localities where lamps were likely to attract beetles at night, based on characteristics of the nearby vegetation and the presence of the beetles themselves. Identification was made in part by use of the key 
and illustrations of Coiffait (11) and in part by sending specimens to specialists (see Acknowledgements).

About 700 specimens of adult meloids were also collected by visual inspection while they were on flowers or stems of different shrubs of the families Astraceae, Compositeae and Leguminoseae. The best time for collecting them was from 10:00 to $15: 30$ when the weather was sunny and warmer than $30^{\circ} \mathrm{C}$. Specimens were collected by hand and transferred to a sodium-cyanide killing bottle. The beetles were pinned, labelled and kept in boxes for further studies. The collected meloids were first identified by the available key and illustrations (7) and subsequently Prof. Bologna received their photographs and character descriptions to confirm the identification (see Acknowledgements).

\section{Collecting Localities}

In order to collect Paederus specimens, Fars province was repeatedly visited in the period from March to October, from 1996 to 1998 and 2006 to 2007, but studies along the southern shore of the Caspian Sea were conducted from April to October, 1999 and 2000. Counties within Sistan and Baluchistan province, on the border of Pakistan, were visited two times in 2005 and 2006 and, finally, we conducted a twoweek survey in Ardebil province, the regions bordering the Republic of Azerbaijan, in the summer of 2006 (Table 2). Our field inspections for collecting blister beetles in the western province of Hamedan and the southern provinces Fars and Hormozgan were conducted, respectively, in 2000 to 2001 and from February to April, 2006 and 2007 (Table 3). Geographic locations of all the collection sites are illustrated in Figure 6. 
M.R. Nikbakhtzadeh and S. Tirgari MEDICALLY IMPORTANT BEETLES (INSECTA: COLEOPTERA) OF IRAN. J. Venom. Anim. Toxins incl. Trop. Dis., 2008, 14, 4, p. 605

Table 2. Paederus beetles (Coleoptera: Staphylinidae) in Iran: faunal diversity and collection localities of reported dermal lesions

\begin{tabular}{|c|c|c|c|c|}
\hline Species & Date of collection & Geographic location & $\begin{array}{l}\text { Collection } \\
\text { point }\end{array}$ & Grid ref. \\
\hline $\mathrm{PI}^{\mathrm{a}}$ & $\begin{array}{l}\text { May-June } \\
2006-2007\end{array}$ & Fars province & Darab & $\begin{array}{l}\text { N } 28^{\circ} 45^{\prime} \\
\text { E } 54^{\circ} 32^{\prime}\end{array}$ \\
\hline $\mathrm{PIL}^{\mathrm{b}}$ & July 1997 & Fars province & Noor-Abad & $\begin{array}{l}\text { N } 30^{\circ} 05^{\prime} \\
\text { E } 51^{\circ} 30^{\prime}\end{array}$ \\
\hline $\mathrm{PF}^{\mathrm{C}}$ & August 1999 & Caspian Sea shore & Ramsar & $\begin{array}{l}\text { N } 36^{\circ} 54^{\prime} \\
\text { E } 50^{\circ} 39^{\prime}\end{array}$ \\
\hline $\mathrm{PK}^{\mathrm{d}}$ & July 1999 & Caspian Sea shore & Tonkabon & $\begin{array}{l}\text { N } 36^{\circ} 49^{\prime} \\
E 50^{\circ} 53^{\prime}\end{array}$ \\
\hline $\mathrm{PB}^{\mathrm{e}}$ & May 2000 & Caspian Sea shore & Noor & $\begin{array}{l}\text { N } 36^{\circ} 37^{\prime} \\
E 52^{\circ} 12^{\prime}\end{array}$ \\
\hline $\mathrm{PL}^{f}$ & June 2000 & Caspian Sea shore & Chamkhaleh & $\begin{array}{l}\text { N } 37^{\circ} 13^{\prime} \\
\mathrm{E} 50^{\circ} 12^{\prime} \\
\end{array}$ \\
\hline $\mathrm{PLI}^{\mathrm{g}}$ & June 2006 & Ardebil Province & Pars-Abad & $\begin{array}{l}\mathrm{N} 39^{\circ} 39^{\prime} \\
\mathrm{E} 47^{\circ} 55^{\prime}\end{array}$ \\
\hline$P C^{h}$ & June 2006 & Ardebil Province & Pars-Abad & $\begin{array}{l}\text { N } 39^{\circ} 39^{\prime} \\
\text { E } 47^{\circ} 55^{\prime}\end{array}$ \\
\hline$P N^{i}$ & $\begin{array}{c}\text { March } \\
2005-2006\end{array}$ & $\begin{array}{c}\text { Sistan and } \\
\text { Baluchistan province } \\
\text { Khash county }\end{array}$ & $\begin{array}{l}\text { Downhill of } \\
\text { Mt. Taftan }\end{array}$ & $\begin{array}{l}\text { N 28 } 30^{\circ} \\
\text { E } 61^{\circ} 07^{\prime}\end{array}$ \\
\hline
\end{tabular}

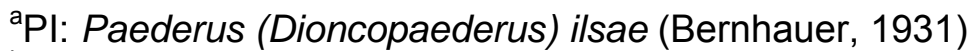

bPIL: Paederus (Heteropaederus) iliensis (Coiffait, 1970)

'PF: Paederus (Heteropaederus) fuscipes (Curtis, 1840)

${ }^{\mathrm{D}} \mathrm{PK}$ : Paederus (Heteropaederus) kalalovae (Roubal, 1932)

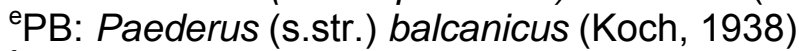

fPL: Paederus (Dioncopaederus) lenkoranus (Scheerpeltz, 1957)

${ }^{9} \mathrm{PLI}$ : Paederus (Dioncopaederus) littoralis (Gravenhorst, 1802)

hPC: Paederus (Dioncopaederus) carpathicus (Wendeler, 1926)

'PN: Paederus (Eopaederus) nigricornis (Bernhauer, 1911) 
Table 3. Blister beetles (Coleoptera: Meloidae) in Iran: faunal diversity and collection localities of reported dermal lesions

\begin{tabular}{|c|c|c|c|c|}
\hline Species & $\begin{array}{c}\text { Date of } \\
\text { collection }\end{array}$ & $\begin{array}{c}\text { Geographic } \\
\text { location }\end{array}$ & Collection point & Grid ref. \\
\hline $\mathrm{Ml}^{\mathrm{a}}$ & June 2001 & $\begin{array}{l}\text { Hamedan } \\
\text { province }\end{array}$ & $\begin{array}{l}\text { North of Toyserkan } \\
\text { (Toyserkan county) }\end{array}$ & 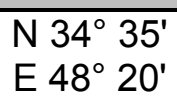 \\
\hline $\mathrm{MIR}^{\mathrm{b}}$ & June 2001 & $\begin{array}{l}\text { Hamedan } \\
\text { province }\end{array}$ & $\begin{array}{c}\text { Oshtormol } \\
\text { (Toyserkan county) }\end{array}$ & $\begin{array}{l}\text { N 34 } 34^{\circ} \\
E 48^{\circ} 18^{\prime}\end{array}$ \\
\hline$M G^{\mathrm{C}}$ & July 2001 & $\begin{array}{l}\text { Hamedan } \\
\text { province }\end{array}$ & $\begin{array}{c}\text { Firoozan } \\
\text { (Nahavand county) }\end{array}$ & $\begin{array}{l}\mathrm{N} 34^{\circ} 17^{\prime} \\
\mathrm{E} \mathrm{48^{ \circ }} 11^{\prime}\end{array}$ \\
\hline $\mathrm{AS}^{\mathrm{d}}$ & March 2006 & Fars province & $\begin{array}{c}\text { Seyf-Abad } \\
\text { (Kazeroon county) }\end{array}$ & $\begin{array}{l}\text { N 29०30' } \\
\text { E } 51^{\circ} 42^{\prime}\end{array}$ \\
\hline $\mathrm{ES}^{\mathrm{e}}$ & $\begin{array}{c}\text { February } \\
2006\end{array}$ & $\begin{array}{l}\text { Hormozgan } \\
\text { province }\end{array}$ & $\begin{array}{c}\text { Minab } \\
\text { (Minab county) }\end{array}$ & $\begin{array}{l}\text { N } 27^{\circ} 05^{\prime} \\
\text { E } 57^{\circ} 04^{\prime}\end{array}$ \\
\hline
\end{tabular}

${ }^{a} \mathrm{MI}$ : Mylabris (Eumylabris) impressa (Chevrolat, 1837)

bMIR: Muzimes iranicus (Maran, 1942)

'MG: Mylabris (s. str.) guerini (Chevrolat, 1837)

${ }^{\mathrm{d} A S:}$ Alosimus smyrnensis (Maran, 1942)

${ }^{\mathrm{E} E S}$ : Epicauta sharpi (Marseul, 1875)

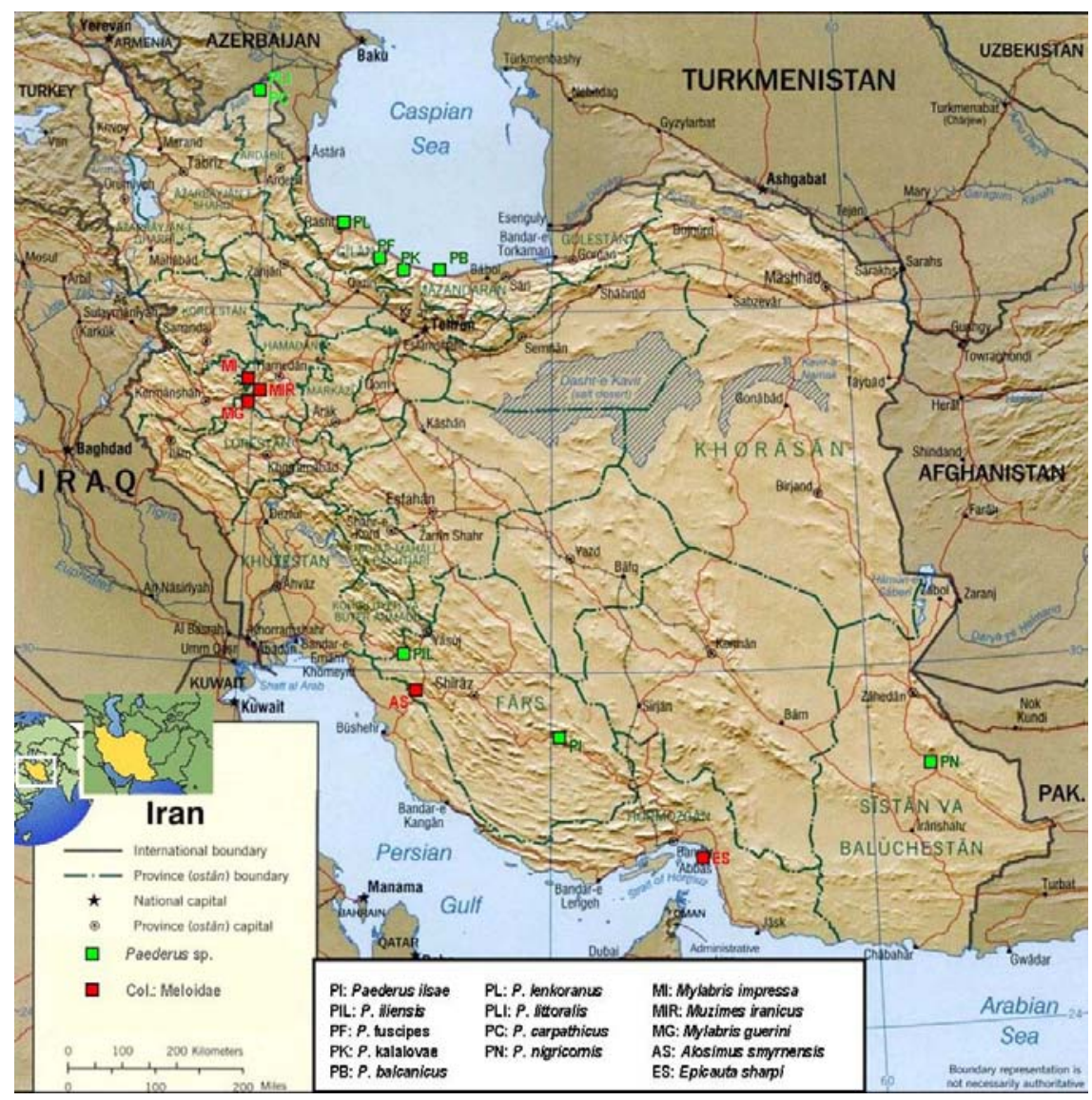

Figure 6. Distribution map of medically important beetles in Iran. 


\section{Calculating the Annual Generation}

By continuous monitoring of the involved beetles and their population dynamics, we could find all peaks of the insects' activity and thus calculate the number of generations per year (Tables 4 and 5). It was possible based on the method, previously applied by two research groups $(18,26)$, which correlates the number of yearly adult peaks with the annual generations of a defined species.

Table 4. Ecological status of predominant Paederus species (Coleoptera: Staphylinidae) in different localities where linear dermatitis was found in Iran

\begin{tabular}{ccccccc}
\hline Species & $\begin{array}{c}\text { Beginning of } \\
\text { adult activity }\end{array}$ & $\begin{array}{c}\text { End of adult } \\
\text { activity }\end{array}$ & $\begin{array}{c}\text { Population } \\
\text { peaks }\end{array}$ & $\begin{array}{c}\mathbf{1}^{\text {st }} \\
\text { peak }\end{array}$ & $\begin{array}{c}\mathbf{2}^{\text {nd }} \\
\text { peak }\end{array}$ & $\begin{array}{c}\mathbf{3}^{\text {rd }} \\
\text { peak }\end{array}$ \\
\hline PF & Mid April & Mid Oct. & 3 & $\begin{array}{c}\text { Mid } \\
\text { June }\end{array}$ & $\begin{array}{c}\text { Mid } \\
\text { Aug. }\end{array}$ & $\begin{array}{c}\text { Mid } \\
\text { Sept. }\end{array}$ \\
\hline PI & Early April & Late Sept. & 2 & $\begin{array}{c}\text { Early } \\
\text { June }\end{array}$ & $\begin{array}{c}\text { Early } \\
\text { Aug. }\end{array}$ & - \\
\hline PIL & Early April & Mid Oct. & 2 & $\begin{array}{c}\text { Late } \\
\text { May }\end{array}$ & $\begin{array}{c}\text { Late } \\
\text { July }\end{array}$ & - \\
\hline PLI & Early June & Late Aug. & 1 & $\begin{array}{c}\text { Mid } \\
\text { July }\end{array}$ & - & - \\
\hline PN & Early March & Early Sept. & 2 & Mid & Mid & - \\
\hline
\end{tabular}

Table 5. Ecological status of predominant blister beetles (Coleoptera: Meloidae) in different localities where meloid dermatitis was reported in Iran

\begin{tabular}{ccccc}
\hline Species & $\begin{array}{c}\text { Beginning of adult } \\
\text { activity }\end{array}$ & $\begin{array}{c}\text { End of adult } \\
\text { activity }\end{array}$ & $\begin{array}{c}\text { Population } \\
\text { peak }\end{array}$ & $\begin{array}{c}\text { N. of yearly } \\
\text { generation }\end{array}$ \\
\hline MI & Late May & Mid July & 1 & 1 \\
\hline AS & Mid March & Mid April & 1 & 1 \\
\hline ES & Late Feb. & Early April & 1 & 1 \\
\hline
\end{tabular}

\section{RESULTS}

\section{Regions that Present Dermatitis Cases}

The majority of insect-induced dermatitis in the country is concentrated in the northern provinces, along the shore of Caspian Sea. This is a narrow coastal region with more than 6.5 million inhabitants. A significant proportion of these cases consist of linear dermatitis which is highly prevalent in the region. This type of lesion is induced by the genus Paederus, which occurs as adults from mid April to October. There are outbreaks of linear dermatitis every year during the spring and summer and the highest incidences are registered from May to August $(30,45)$. To the 
northwest, very close to the international border of the Republic of Azerbaijan, we collected Paederus beetles that were responsible for the summer sporadic cases of linear dermatitis (Table 2). The seasonal activity of the adult beetles in Pars-Abad is probably short, hence the beetles have little time to affect local people.

Fars province, in southern Iran, ranks second in number of reported dermatitis cases. Similarly to the northern region, most cases are provoked by Paederus beetles (33). Outbreaks in Noor-Abad and Darab occurred in 1997 and 2007, respectively (Table 2). The outbreak occurrences are near the midpoint of adult beetle seasonal activity, which begins in early April and continues until September or October (Table 4). Blister beetles are also active in Fars province and the suburbs of Kazeroon county have been once affected since the beginning of our studies, in 2006 (Table 3). In the Kazeroon climate, adult meloids appear in mid March, earlier than Paederus beetles, and are active for one month (Table 5).

The third major region in which insect-induced dermatitis has been recorded is Hamedan province, in the west of the country, specifically, cases of blistering from meloids (Table 3). The problem had its highest severity in 2001, when a considerable number of patients sought medical help in Toyserkan and Nahavand counties, where meloid adults are active from late May until mid July (Table 5).

New cases of blistering were reported in Minab, in the Hormozgan province, near the Persian Gulf coast; the agent was identified as a meloid beetle (Table 3). Due to the warmer climate of the Persian Gulf coastal areas, the adult meloids are present from late February to early April (Table 5). In all these regions, it was observed that the outbreaks, or the recorded dermatitis cases, precisely coincided with the yearly peaks of the involved beetles.

\section{Predominant Species and Their Ecological Status}

The diversity of Paederus and meloid species in each studied locality is summarized in Tables 2 and 3, respectively. According to Table 2, four species of Paederus beetles were collected along the southern shore of the Caspian Sea ( $P$. balcanicus, $P$. lenkoranus, $P$. kalalovae and $P$. fuscipes), among which $P$. fuscipes (Figure 7 ) and P. kalalovae are dominant. These two species comprised 3,450 of $5,118(67.4 \%)$ specimens that were collected in the north. It appears that $P$. fuscipes presents an almost uniform distribution along the Caspian Sea region, while the three other species are more concentrated. Based on our personal observations of patient 
numbers and due to its widespread distribution, $P$. fuscipes is probably the most responsible for linear dermatitis in northern Iran. Farther to northwest, Paederus littoralis (Figure 8) is the most frequent species in Pars-Abad, where it constituted 362 of $503(72 \%)$ collected specimens. It seems that both species, Paederus ilsae (Figure 9) and Paederus iliensis (Figure 10), were identified in Fars province and are of considerable medical importance. Paederus ilsae was responsible for all cases of linear dermatitis in Darab, during the summer 2007 outbreak, when at least 60 cases requiring attention were recorded. In southern Iran, in Noor-Abad and the nearby town of Kazeroon, most summer cases of dermatitis probably resulted from exposure to Paederus iliensis, which was the only recorded species in the region.

Hibernating Paederus beetles can be found under rocks and dwell in the ground (Figure 11). Among the three species of blister beetles, collected in the western province of Hamedan (272 specimens), Mylabris impressa (Figure 12) was the dominant one with a predominance of $80 \%$. The ecological status of the major Paederus and meloid beetles is summarized in Tables 4 and 5 , respectively.

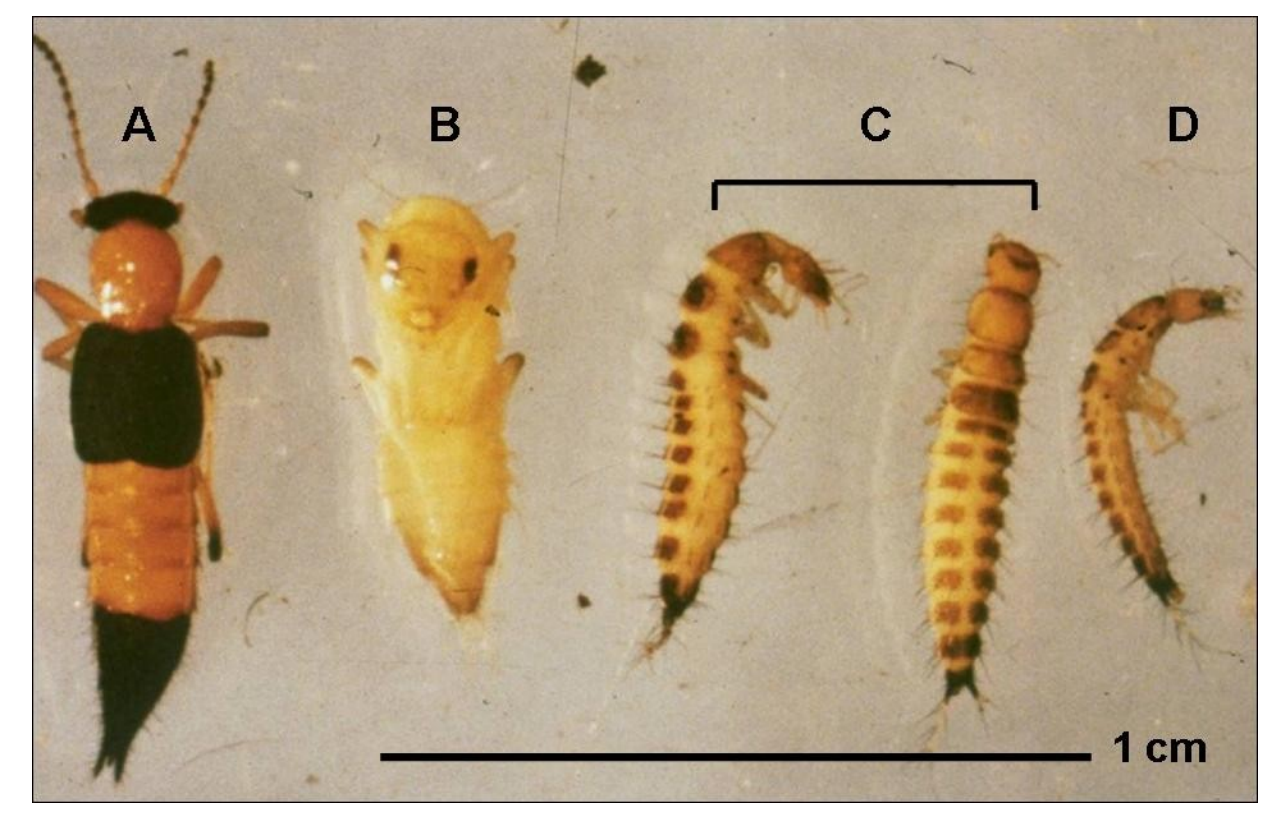

Figure 7. Adult (A), pupa (B), second instar (C) and first larval instar (D) of Paederus fuscipes (Caspian Sea shore). 
M.R. Nikbakhtzadeh and S. Tirgari MEDICALLY IMPORTANT BEETLES (INSECTA: COLEOPTERA) OF IRAN. J. Venom. Anim. Toxins incl. Trop. Dis., 2008, 14, 4, p. 610

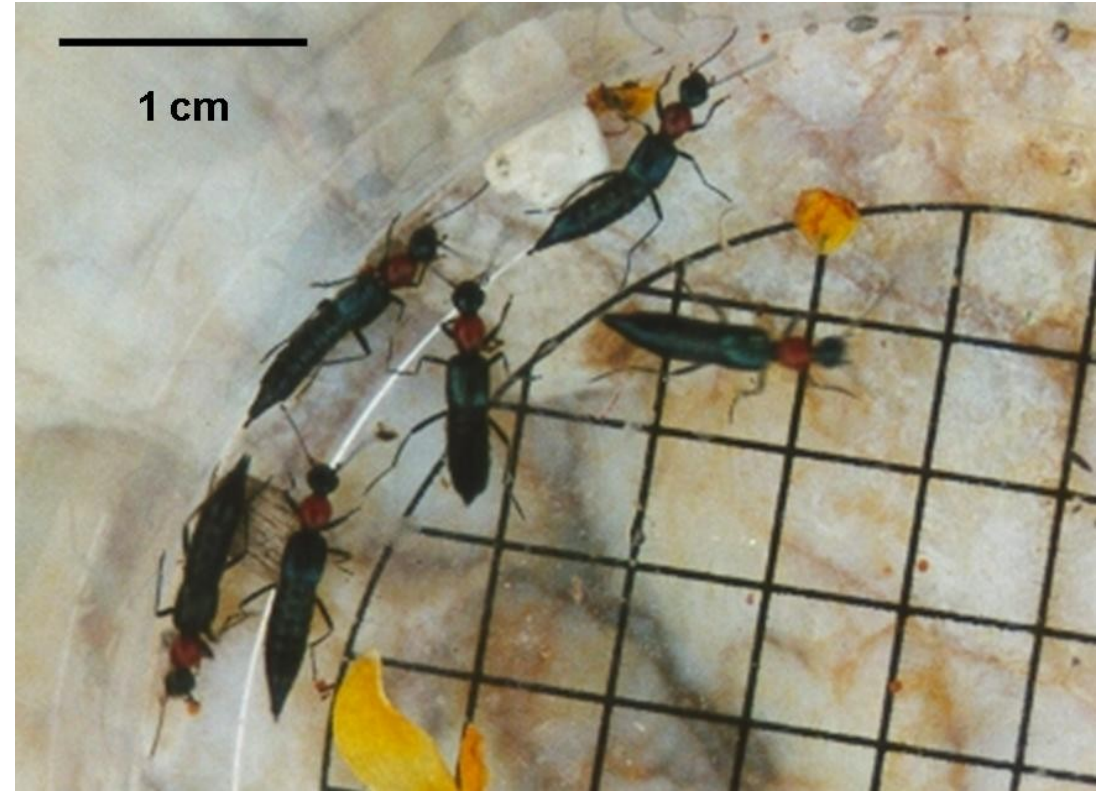

Figure 8. Paederus littoralis, a frequent species of Pars-Abad district, north-western Iran.

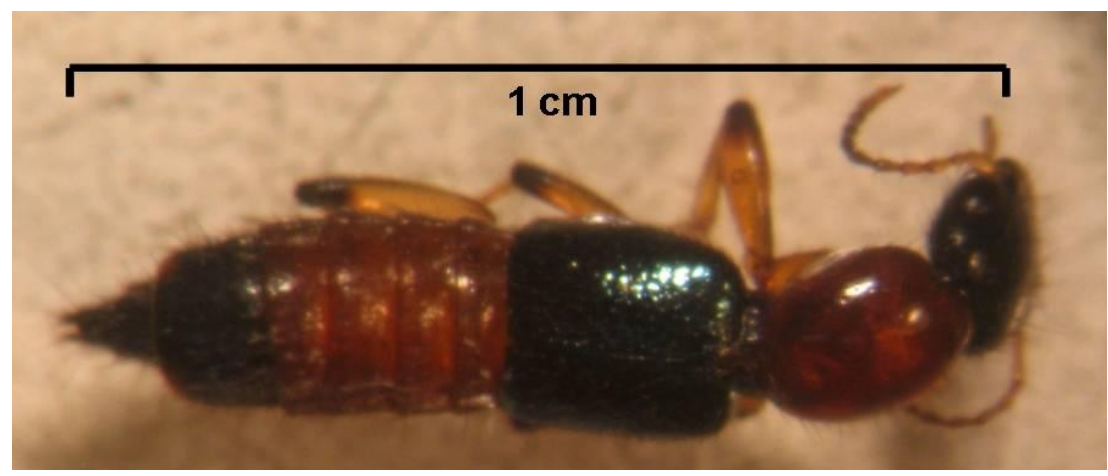

Figure 9. Paederus ilsae, the predominant species in Darab, Fars province, southern Iran.

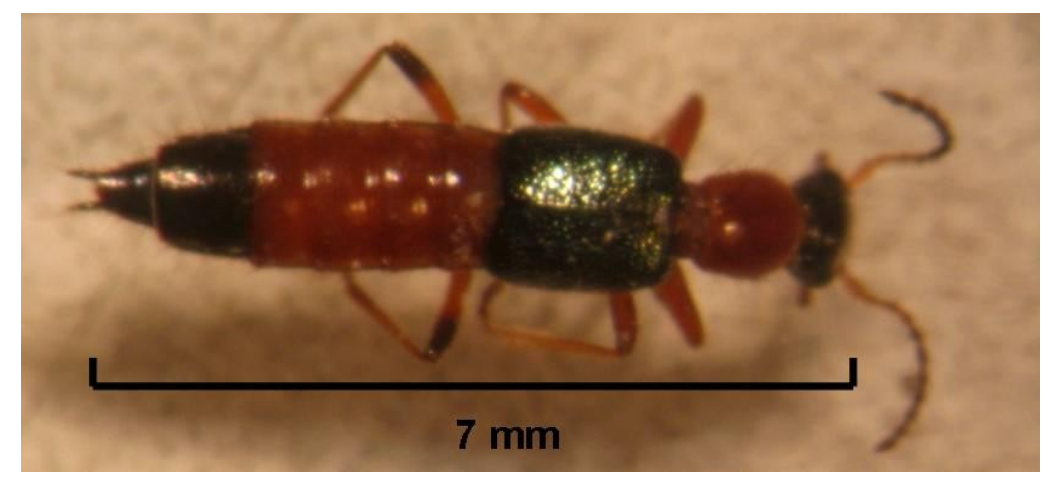

Figure 10. Paederus iliensis, the only recorded species of Noor-Abad and Kazeroon counties, Fars province, southern Iran. 
M.R. Nikbakhtzadeh and S. Tirgari MEDICALLY IMPORTANT BEETLES (INSECTA: COLEOPTERA) OF IRAN. J. Venom. Anim. Toxins incl. Trop. Dis., 2008, 14, 4, p. 611

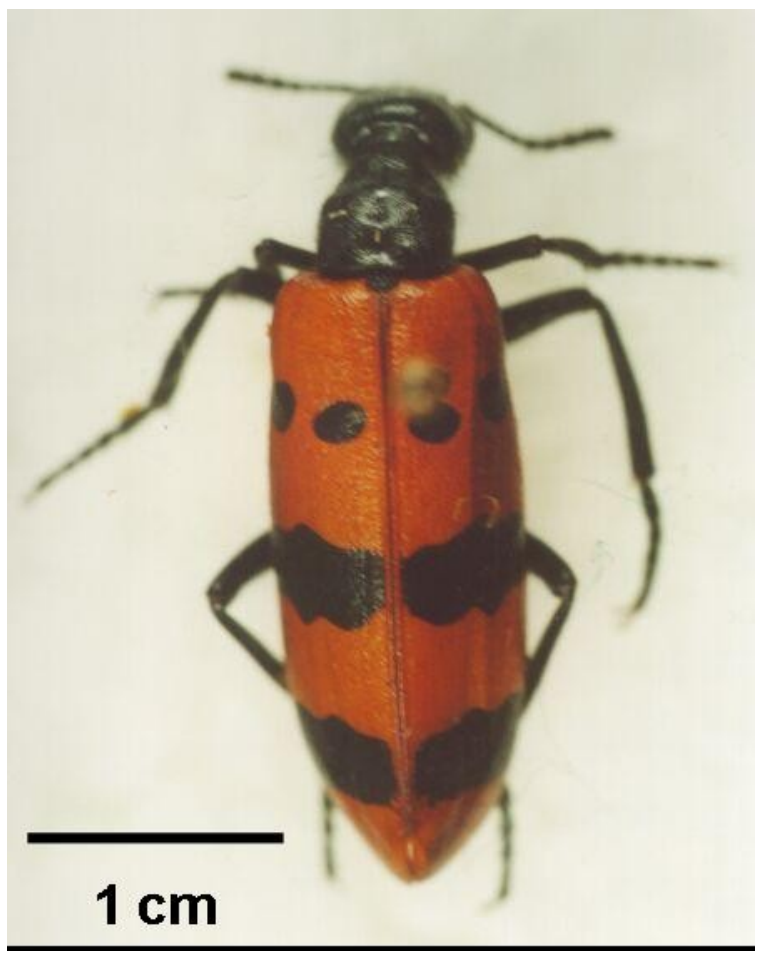

Figure 11. Mylabris impressa (Coleoptera: Meloidae), the predominant species in the western province of Hamedan.

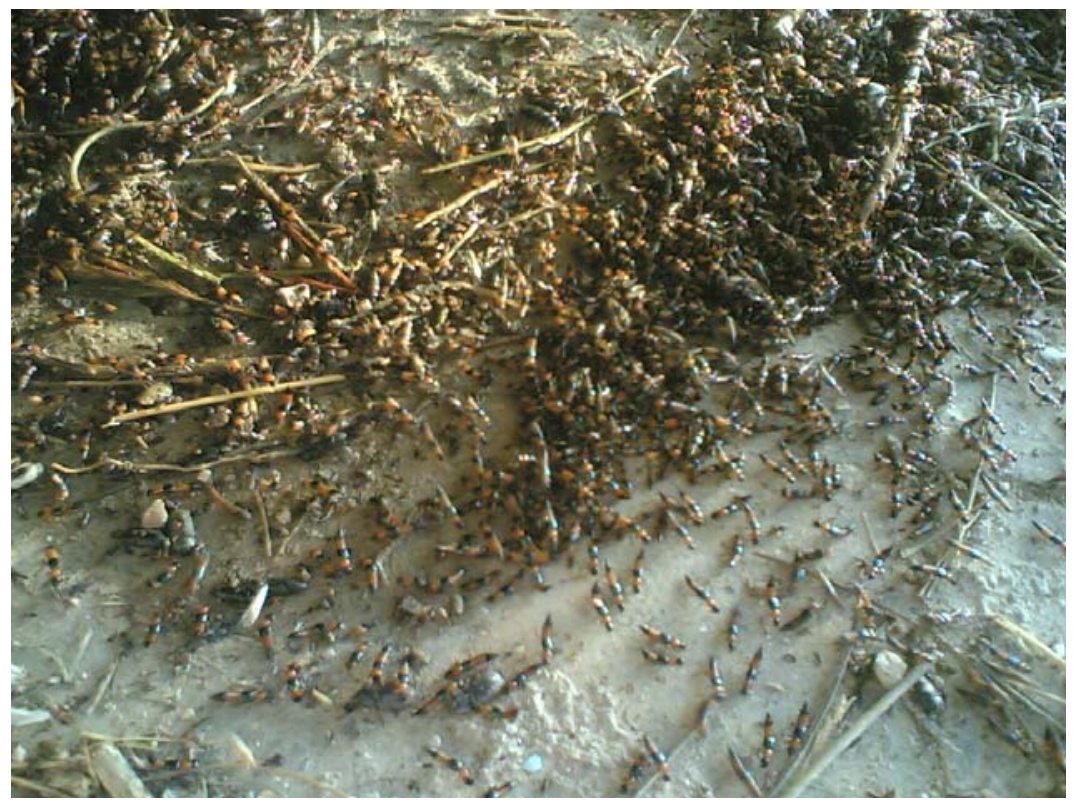

Figure 12. Hibernating Paederus beetles under rocks. 


\section{DISCUSSION}

Climatic differences between southern and northern Iran create specific epidemiological features of linear dermatitis. Whereas it is a rural problem in the south, mainly seen in villages or small towns, these skin involvements are a major urban problem in the northern provinces of Iran, along the Caspian Sea. In the north, people seek clinical treatment between June and September every year; rural workers may miss many days of work until lesions have healed and tourists can be also affected. The Caspian Sea shore has popular residential locations and its human population is distributed almost uniformly. In addition to the 6.5 million local residents, the region is also visited annually by over 15 million tourists. This high population density is ideal for maximum contact between Paederus beetles and humans. On the contrary, other parts of Iran, particularly the south, are less populated: villages are kilometres away from each other and farming is restricted to regions with sufficient access to water.

In the west and south, Paederus is found mainly in wet areas near rivers and ponds, among dense vegetation canopies and field crops under irrigation. It is also possible that wet and sticky skin, resultant from the humid climate of the Caspian Sea region, provokes more severe symptoms and, thus, more reported cases. Wet and sticky skin may facilitate local penetration of insect toxins and therefore enhance deleterious effects. Lower relative humidity in the south and perhaps associated drier skins reduce harmful effects of the insect hemolymph.

Paederus hibernates in the adult stage (Figure 11). When crops are harvested, the beetles move to weeds as an alternative shelter and remain there until spring, when field crops reappear. There may be several generations during the year, but winter imposes quiescence; consequently, breeding does not recommence until spring (29). Most cases of linear dermatitis are caused after dusk, when people are at home and artificial lights are in use. Adult beetles, attracted by these lights, inadvertently land on human skin.

It was recently found that Paederus males have only small quantities of the toxin $(0.1$ to $1.5 \mu \mathrm{g}$ ), while females present up to ten times more pederin $(0.2$ to $20 \mu \mathrm{g})$. Females, themselves, can also be divided into two groups according to pederin proportion. Positive (+) females predominate in every generation, whereas the negative ones (-) are the minority. So, there is a polymorphism in hemolymph toxin of Paederus beetles (23). Pederin polymorphism is another factor that must be 
considered in the provocation of linear dermatitis, since positive females constitute most of the Paederus population. Prevention may be achieved by removing the vegetation from dwellings, by draining flooded areas, by equipping doors and windows with screens and by avoiding fluorescent and neon lamps (13). Nikbakhtzadeh (29) and Poormusa (35) indicated that limited application of residual insecticides around fluorescent and neon lamps in human residences effectively reduced adult Paederus populations.

The current study is the first report on the medical importance of Iranian meloids. Although over hundred species of blister beetles have so far been reported in Iran, merely a few present any medical importance. Adult meloids are only periodically active in nature, presumably in response to variable heat and humidity. Thus, meloid dermatitis also shows a biennial pattern in the studied regions. In hot arid areas, it was found that adults tend to remain on or near the ground, under dense foliage for the most of the day. Meloid dermatitis is restricted primarily to those persons who spend longer periods outdoors; especially farmers and other agricultural workers.

An interesting aspect is the gregarious behavior of these beetles (40) which creates a patchy distribution and restricts the incidence of dermatitis to a limited area. Meloids bear one generation per year, hence they present only one population peak annually. The long complicated life cycle of these insects, highly selective feeding behavior, patchy distribution and obligatory diapause prevent any population outbreak from occurring.

It is well established that in many species of blister beetles, females possess, but cannot produce, cantharidin. During copulation, males transfer large amounts of cantharidin along with sperm to females. This type of "nuptial gift" provides chemical protection to the beetle, by passing on cantharidin to eggs (38). The possibility that cantharidin is transferred from the male to the female during mating was suggested long ago (5) and, more recently, has been confirmed by many researchers $(20,27$, 39). Cantharidin content varies interspecifically $(9,10,15,32)$. Differences may also depend on factors such as sex, age, size (weight) and copulation history. Among specimens provided by victims, both meloid beetle sexes were present; and no sex differences were apparent in inducing the blistering symptoms. In two blistering cases, the agents were Muzimes iranicus females that had recently copulated (a male spermatophore was observable in the external genitalia). This situation agrees with our previous data on blister beetles, since females who have copulated must 
have received a large volume of cantharidin from their male partners. We still do not know whether all involved females had recently copulated; and further work is necessary to confirm this.

So far, meloid dermatitis has been recorded in the western and southern Iran (Table 3 ); however, the status of the problem is not yet clear in the other provinces of the country. This is perhaps due to the very low number of annual cases, the shortage of medical documentation, the passive case detection (PCD) of human blistering, applied in this study, or to misdiagnosis. PCD normally covers a specific time frame (temporal distribution of cases) whereas active case detection (ACD) potentially covers places (spatial distribution of cases). Since no ACD was conducted, some cases that in fact presented the problem, but for some reason had not come to our attention, might have been missed. However, it is clear that meloid-induced dermatitis is not as widespread as linear dermatitis and remains a minor rural health problem.

\section{ACKNOWLEDGEMENTS}

We thank Dr. Howard Frank, University of Florida, who identified some of our Paederus specimens from southern Iran and supplied copies of articles from the literature. Dr. Peter Hammond, London Natural History Museum, kindly confirmed the identification of some Paederus beetles. We also thank Dr. Marco Bologna, University of Rome, for reviewing our meloid specimens and Dr. Mohammad Omrani and Dr. Shahyad Azari, Tehran University, for their very helpful comments on the first draft of this article. We are grateful to Dr. John Sloggett (Netherlands) and Dr. Johannes Lückmann (Germany) for careful reviewing the manuscript draft, for their scientific remarks and for improving the English text. Figure 4 is credited to Samuel Grubb at the University of Florida; the permission to reproduce it was kindly issued by Tom Fasulo, University of Florida. We are thankful to both of these scientists.

Kind cooperation of our MSc students (Mohammad Rasoolian and also Mehran Shahi), Abbas Mohammadi Khoramabadi, Darab School of Agriculture and Mohammad Reza Abai, Tehran University of Medical Sciences, must herein be acknowledged. Transportation and accommodation in many regions were provided by the National Health Network. 


\section{REFERENCES}

1 AHMED AR., MOY R., BARR AR., PRICE Z. Carpet beetle dermatitis. J. Am. Acad. Dermatol., 1981, 5, 428-32.

2 ALEXANDER JOD. Arthropods and human skin. Berlin: Springer-Verlag, 1984. 422 p.

3 AXENTIEV SI. Meloidae from Iran (Insecta: Coleoptera). Senkenbergiana Biol., 1985, 65, 245-50.

4 BANNEY LA., WOOD DJ., FRANCIS GD. Whiplash rove beetle dermatitis in central Queensland. Australas. J. Dermatol., 2000, 41, 162-7.

5 BEAUREGARD H. Les insectes vesicants. Paris: Felix Alcan, 1890. 544p.

6 BHARGAVA RK., GUPTA B. Seasonal blistering dermatitis. J. Indian. Med. Assoc., 1982, 79, 95-6.

7 BOLOGNA MA. Coleoptera Meloidae. Fauna D'Italia. Bologna: Edizioni Calderini, 1991. 541p.

8 BOLOGNA MA., D'INZILLO B., CERVELLI M., OLIVERIO M., MARIOTTINI P. Molecular phylogenetics of the Mylabrini blister beetles (Coleoptera: Meloidae). Mol. Phylogenet Evol., 2005, 37, 306-11.

9 CAPINERA JL., GARDNER DR., STERMITZ FR. Cantharidin levels in blister beetles (Coleoptera: Meloidae) associated with alfalfa in Colorado. J. Econ. Entomol., 1985, 78, 1052-5.

10 CARREL JE., EISNER T. Cantharidin: potent feeding deterrent to insects. Science, 1974, 183, 755- 6.

11 COIFFAIT H. Coléoptères Staphylinidae de la région Paléarctique occidentale. IV. Sous-famille Paederinae. Tribus Paederini 1 (Paederi, Lathrobii). Suppl. Nouv. Rev. Entomol., 1982, 12, 440p.

12 CORMIA FE., LEWIS GM. Contact dermatitis from beetles with a report of a case due to the carpet beetle (Anthrenus scrophularia). N.Y. State J. Med., 1948, 48, 2037-9.

13 COUPPIÉ P., BEAU F., GROSSHANS E. Paederus dermatitis: àpropos d'une épidémie à Conakry (Guinée) en novembre 1989. Ann. Dermatol. Venereol., 1992, $119,191-5$.

14 DETTNER K. Inter and intraspecific transfer of toxic insect compound cantharidin. In: DETTNER, K., BAUER, G., VÖLKL W. Eds. Vertical food web interactions. Berlin: Springer-Verlag, 1997. 115-45p. 
15 DIXON AFG., MARTIN-SMITH M., SMITH SJ. Isolation of cantharidin from Melöe proscarabeus. Can. Pharmaceutical J., 1963, 29, 501-3.

16 FLEISHER TL., FOX I. Oedemerid beetle dermatitis. Arch. Dermatol., 1970, 101, 601-5.

17 FRANK JH. Paederus, sensu lato (Coleoptera: Staphylinidae): an index and review of the taxa. Insecta Mundi, 1988, 2, 97-159.

18 FRANK JH., KANAMITSU K. Paederus, sensu lato (Coleoptera: Staphylinidae): natural history and medical importance. J. Med. Entomol., 1987, 24, 155-91

19 HARWOOD RF., JAMES MT. Entomology in human and animal health. 7.ed. New York: MacMillan Publishing Co., 1979. 548p.

20 HOLZ C., STREIL G., DETTNER K., DÜTEMEYER J., BOLAND W. Intersexual transfer of a toxic terpenoid during copulation and its parental allocation to developmental stages: quantification of cantharidin in cantharidin-producing oedemerids (Coleoptera: Oedemeridae) and canthariphilous pyrochroids (Coleoptera: Pyrochroidae). Z. Naturforsch., 1994, 49c, 856-64.

21 JANBAKHSH B., ARDALAN A. Rove beetles (Coleoptera: Staphylinidae) and their medical importance. Iranian J. Publ. Health, 1977, 6, 70-7.

22 KASZAB Z. Contribution a la faune de I'Iran (Coleopteres : Meloidae). Ann. Soc. Ent. Fr (N.S.)., 1968, 4, 749-76.

23 KELLNER RLL., DETTNER K. Allocation of pederin during lifetime of Paederus rove beetles (Coleoptera: Staphylinidae): evidence for polymorphism of hemolymph toxin. J. Chem. Ecol., 1995, 21, 1719-33.

24 LEHMANN CF., PIPKIN JL., RESSMANN AC. Blister beetle dermatosis. AMA Arch. Dermatol., 1955, 71, 36-8.

25 MAJIDI-SHAD B., JANBAKHSH B., BAGHERI-ZENOOZ E. The species of genus Paederus in the southern region of the Caspian Sea (abstract). In: PROCEEDINGS OF THE $9^{\text {th }}$ PLANT. PROTECTION CONGRESS OF IRAN, Mashhad., 1989, 9-14. 26 MANLEY GV. Paederus fuscipes (Col.: Staphylinidae): a predator of rice fields in west Malaysia. Entomoph., 1977, 22, 47-59.

27 MCCORMICK JP., CARREL JE. Cantharidin biosynthesis and function in meloid beetles. In: PRESTWITCH, GD., BLOMQUIST, GJ. Eds. Pheromone biochemistry. Orlando: Academic Press, 1987. 307-50p. 
28 MCCRAE AW., VISSER SA. Paederus (Coleoptera: Staphylinidae) in Uganda. I: Outbreaks, clinical effects, extraction and bioassay of the vesicating toxin. Ann. Trop. Med. Parasitol., 1975, 69, 109-20.

29 NIKBAKHTZADEH MR. Identification and bioecology of Paederus beetles (Col.: Staphylinidae) causing linear dermatitis in central and western parts of Fars province, Iran. Tehran, Tarbiat Modares University, College of Medical Sciences, 1998. 251p. [Master's thesis].

30 NIKBAKHTZADEH MR., SADEGHIANI C. Dermatite due à deux espèces de Paederus au sud de l'Iran. Bull. Soc. Path. Exot., 1999, 92, 56.

31 NIKBAKHTZADEH MR., TIRGARI S. Blister beetles (Coleoptera: Meloidae) in Nahavand county (Hamedan province, Iran) and their ecological relationship to other Coleopteran families. Iranian J. Publ. Health, 2002, 31, 55-62.

32 NIKBAKHTZADEH MR., TIRGARI S. Cantharidin component of Iranian blister beetles (Col.: Meloidae) and their differences between Iranian and exotic species. Iranian J. Publ. Health, 2002, 31, 113-7.

33 NIKBAKHTZADEH MR., TIRGARI S. Two medically important beetles of Fars province, Iran. Iranian J. Publ. Health, 1999, 28, 56-69.

34 NIKDEL M. Further studies on biology and dermatitis of genus Paederus (Coleoptera: Staphylinidae) in Ramsar, Iran. Tehran: Tehran University of Medical Sciences, College of Public Health, 1995. 124 p. [Master's thesis].

35 POORMUSA A. The effect of local application of residual insecticides around artificial source of lights in the control of Paederus dermatitis. Tehran, Tehran University of Medical Sciences, College of Public Health, 2002. 110p. [Master's thesis].

36 PORTEVIN G. Coleopteres de France. Paris: Paul Leghevalier ,1928. 389p.

37 REDTENBACHER L. Über den charakter der Insekten- Fauna von Südpersien. Denkschr. Acad. Wiss. Wien, 1850, 1, 42-53.

38 SCHMIDT J. Department of Entomology. Colorado State University. (http://www.colostate.edu/Depts/Entomology/courses/en570/papers_2002/schmidt.ht $\mathrm{m})$.

39 SIERRA JR., WOGGON WD., SCHMIDT H. Transfer of cantharidin during copulation from the adult male to the female Lytta vesicatoria (Spanish flies). Experientia, 1976, 32, 142-4. 
40 SNEAD JS., ALCOCK J. Aggregation formation and assortative mating in two meloid beetles. Evolution, 1985, 39, 1123-31.

41 SOUTHCOTT RV. Injuries from Coleoptera. Med. J. Aust., 1989, 151, 654-9.

42 THEODORIDES J. Considération sur les Paederus vesicans (Coleoptera: Staphylinidae) et essais de vésication avec des espèces de France. Bull. Soc. Path. Exot., 1950, 43, 100-13.

43 TIRGARI S., NIKBAKHTZADEH MR. Paederus beetles (Coleoptera: Staphylinidae): an urban problem in Iran. In: INTERNATIONAL CONFERENCE ON URBAN PESTS, 4, Charleston, South Carolina. 2002, 401-7.

44 WIRTZ RA. Allergic and toxic reactions to non-stinging arthropods. Annu. Rev. Entomol., 1984, 29, 47-69.

45 ZARGARI O., ASADI AK., FATHALIKHANI F., PANAHI M. Paederus dermatitis in northern Iran: a report of 156 cases. Int. J. Dermatol., 2003, 42, 608-12. 